\title{
Development of Magnetic Material Testing Equipment
}

\author{
András NAGY, ${ }^{1}$ Imre NÉMEDI ${ }^{2}$ \\ ${ }^{1}$ University of Dunaújváros, Dunaujvaros, Hungary, nagyandras@uniduna.hu \\ ${ }^{2}$ Technical Vocational College of Serbia, Subotica, Serbia, nimre@vts.su.ac.rs
}

\begin{abstract}
This paper deals with the development of equipment that can accurately determine the magnetic properties of small volume thin plate samples. The alloys to be tested are sheets of amorphous structure, such as Finemet alloy, which has excellent high frequency magnetic properties, making it a good candidate for the construction of high efficiency electric motors. This article discusses the components and operation of the equipment under development, whilst giving a brief overview of the efficiency classification of electric motors and the importance of the emerging efficiency class.
\end{abstract}

Keywords: amorphous, $B H$ curve, magnetic measuring equipment, fluxgate sensor.

\section{Introduction}

This paper discusses the development of a magnetic tester that can accurately determine the magnetic properties of small volume thin plate samples. The alloys to be tested are plates of amorphous structure, such as Finemet alloy, which has excellent high-frequency magnetic properties. In [1] a 6-pole electric motor stator was made of amorphous material, achieving an efficiency of over $90 \%$. The use of amorphous material in BLDC (brushless direct current) motors also shows advantageous properties, in [2] a $1 \mathrm{~kW}$ motor with a speed of 70,000 rpm was built using Metglas 2605 SA1 alloy. Tests have shown that the use of an amorphous material can reduce the heating of the electric motor. [3] gives a comprehensive review of the results of recent applications of amorphous materials in electric motors. A study of a two-pole, $1.2 \mathrm{~kW}$ motor revealed that when using amorphous materials, the loss is reduced by $1 / 5$ [4].

The required minimum efficiency of an electric motor is the function of power, electric motors currently available on the market fall into the IE1-IE3 category. The European Union has issued a regulation [5] on eco-design requirements for electric motors. The emergence of IE4 class motors (,Super premium efficiency”, defined in IEC 60034-30 and IEC 60034-331) requires new technologies and materials to reduce the various losses of electric motors.

In the manufacturing sector, electric motors account for an average $70 \%$ of electricity consumption [6]. It is clear that the goal is better energy efficiency, which means less environmental emissions.

The use of amorphous materials requires that thin amorphous sheets having a thickness of 20$40 \mu \mathrm{m}$ be cut to the proper shape so that machining has the least possible effect on the amorphous structure as well as on the favourable magnetic properties. Cutting experiments [7] show that laser cutting with appropriate technological parameters produces a minimal heat affected zone. Thus, the amorphous material structure is damaged only to the extent that it does not significantly affect the magnetic properties.

This article describes the development of equipment to measure the impact of different cutting technologies on the magnetic properties of a material. Issues and solutions that arise during the development of the equipment and the measurement process are presented along with the circuitry of the equipment. 


\section{The structure of the equipment}

\subsection{Basis of the operation}

The operation of the magnetic tester is based on the fact that when a material is placed in a DC magnetic field, it creates its own magnetic field under excitation. By measuring this, the hysteresis loop can be determined and the resulting values calculated (eg. coercive force, remnant magnetization, etc.). In order to excite the examination sample, the homogeneous magnetic field can be produced in various ways, for example by means of a Helmholtz coil or a solenoid. The magnetic testing apparatus disclosed herein uses a solenoid for this purpose, which creates a highly accurate magnetic field inside (in case of sufficiently accurate geometry) (Figure 1.).

The ferromagnetic pattern placed inside the solenoid creates its own magnetic field under excitation. This evolving magnetic field is also constant over time due to the excitation of DC current, so it is not suitable for measurement by a conventional measuring coil (based on the measurement of voltage induced by a variable magnetic field). In order to select the appropriate magnetic field sensor, it is necessary to determine some of the characteristics that form the basis of the specification.

Figure 2 shows how the sample is located inside the solenoid. The excitatory magnetic field generated by the solenoid produces a magnetic field in the sample which, due to the small volume of the sample, is orders of magnitude weaker than the excited magnetic field.

The essence of the measurement procedure is, therefore, to measure the magnetic field (B) formed by the excitation (magnetic field strength, H) produced with high precision by the solenoid. From this, the B-H curve can be drawn and magnetic properties calculated.

A block diagram of the magnetic tester is shown in Figure 3.

The central control is carried out by a 16-bit PIC microcontroller that communicates with the coil drive circuit, enabling the digital setting of the output current. The sensor interface sub-circuit of the magnetometer performs signal conditioning and isolation, enabling high-resolution digitization. The device communicates with the control software developed for the PC via a digital interface (USB - VCP).

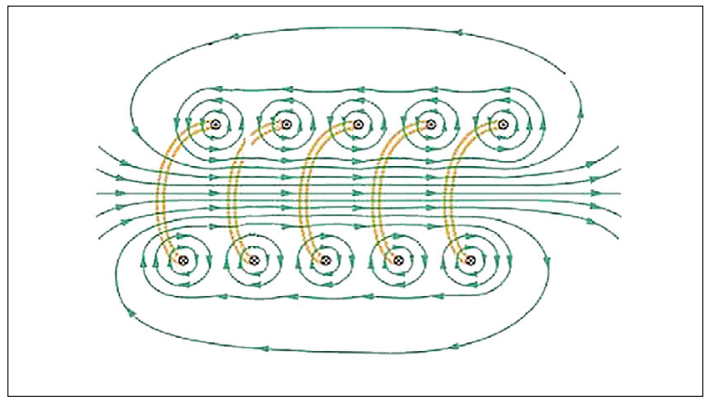

Figure 1. Magnetic field lines formed inside a solenoid.

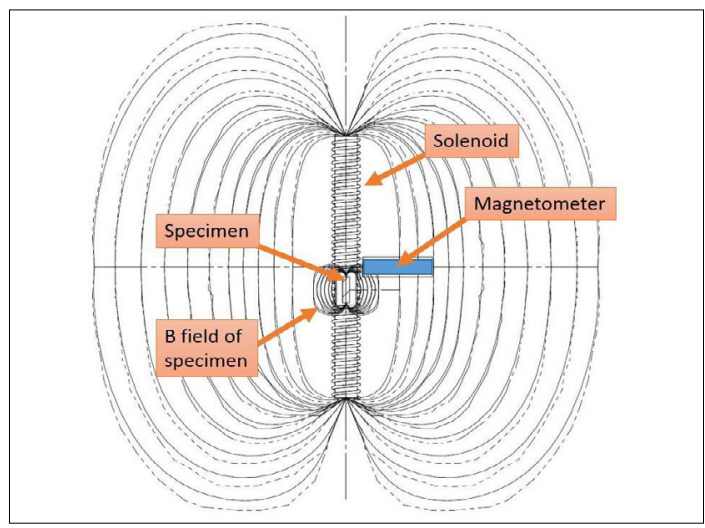

Figure 2. Magnetic field of a sample placed inside a solenoid and the placement of a magnetometer to measure it. [8]

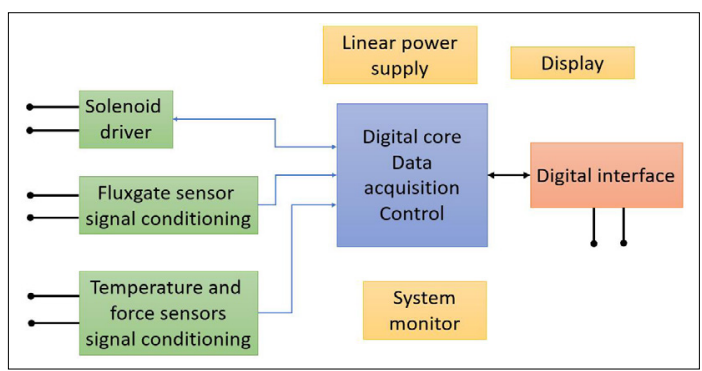

Figure 3. Block diagram of the electronics of the magnetic tester.

\subsection{Solenoid design}

One of the main components of the device is a solenoid producing a homogeneous magnetic field. Within this, the resulting field strength is calculated using the following formula:

$$
\mathrm{H}=(\mathrm{N} \cdot \mathrm{I}) / \mathrm{L}
$$

in which

$\mathrm{H}$ - magnetic field strength, $\mathrm{A} / \mathrm{m}$;

$\mathrm{N}$ - solenoid number of turns;

I - current, A;

$\mathrm{L}$ - length of solenoid, $\mathrm{m}$. 
It can be seen that for a given geometry the field strength can be varied proportionally to the current flowing in the coil in a linear relationship. For the sizing of the solenoid, other contexts were also used, such as Ohm's Law.

Scaling is based on a few recorded data:

- length of solenoid: $500 \mathrm{~mm}$;

- external diameter of solenoid core: $50 \mathrm{~mm}$;

- maximum field strength (min.): $30000 \mathrm{~A} / \mathrm{m}$.

From the initial data the following results were obtained:

- solenoid No. of turns (by layer): 306;

- number of layers: 6;

- solenoid Ohmic resistance: $3.08 \Omega$;

- maximum winding current: $10.3 \mathrm{~A}$;

- coil power dissipation: $332 \mathrm{~W}$;

- wire diameter: $1.6 \mathrm{~mm}$.

The power dissipated by the solenoid is converted into heat, which heats the wire, increasing its resistance. For accurate field strength adjustment, the device is provided with a constant current drive which drives a constant current across the coil regardless of the resistance of the coil. The design of the solenoid and the unit built are shown in Figure 4.

\subsection{Magnetic field sensor}

A carefully selected sensor is required to detect the magnetic field of the excited sample. Figure 5 compares the technology of some magnetometers based on measurement ranges.

Among the requirements for the sensor are the relatively low measurement range $( \pm 10 \mu \mathrm{T})$, the high degree of directional sensitivity and the ability to detect a constant (DC) magnetic field.

Fluxgate sensors are best suited to these requirements.

The working principle of the fluxgate magnetometer is illustrated in Figure 6. The ferromagnetic iron core of figure (a) is driven in saturation periodically by the drive (primary) coil in both positive and negative directions. The variation in flux density can be captured by the sensor (secondary) coil. In the presence of an external magnetic field, this signal becomes asymmetric, the strength of the magnetic field being proportional to the second harmonic of the signal, figure (b).

\section{Component design}

\subsection{Coil Drive Electronics}

The coil drive circuit is essentially a constant current driver and a double $\mathrm{H}$ bridge integrated together. In this way, the direction and magnitude of the current can be changed simultaneously.

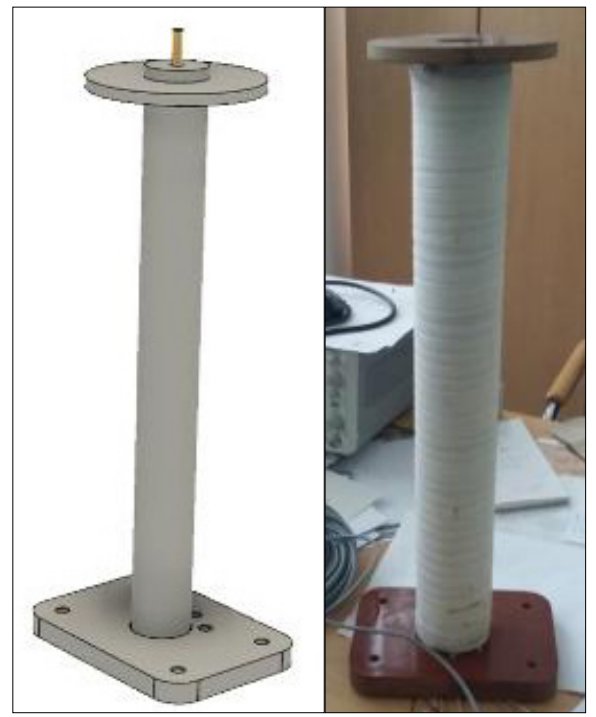

Figure 4. The 3D model (left) of the solenoid and the manufactured solenoid (right).

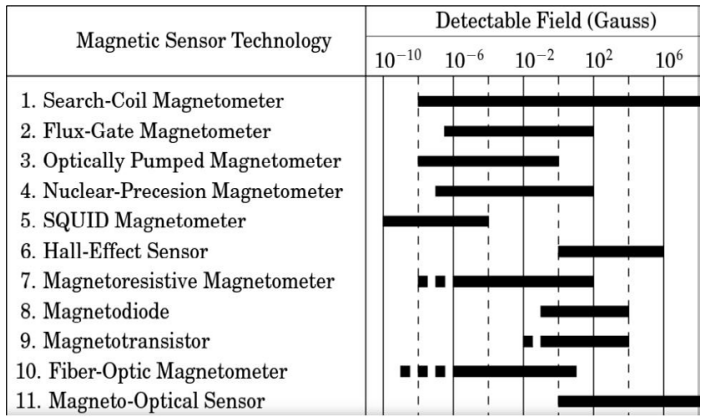

Figure 5. Comparison of magnetic field sensor technologies [9]
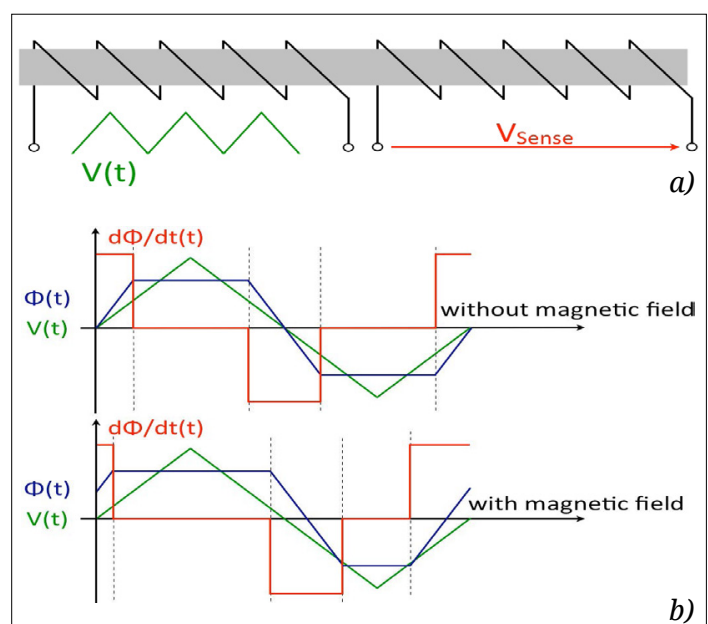

Figure 6. Operating principle of Fluxgate magnetometer [10]. 


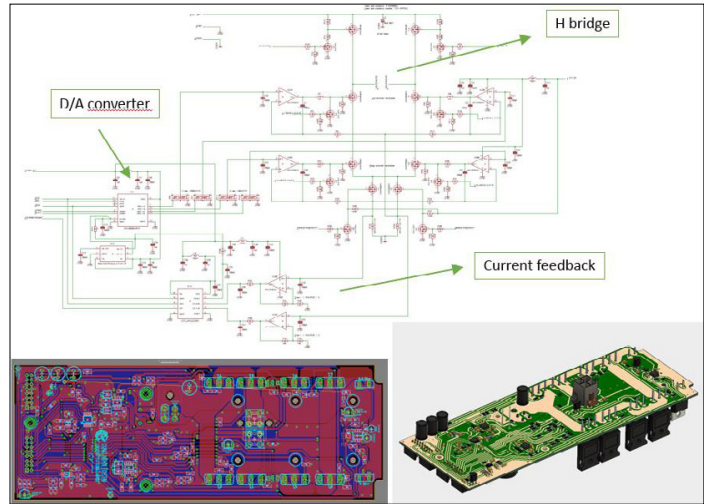

Figure 7. Schematic diagram of coil drive electronics, $P C B$ design and $3 D$ model.

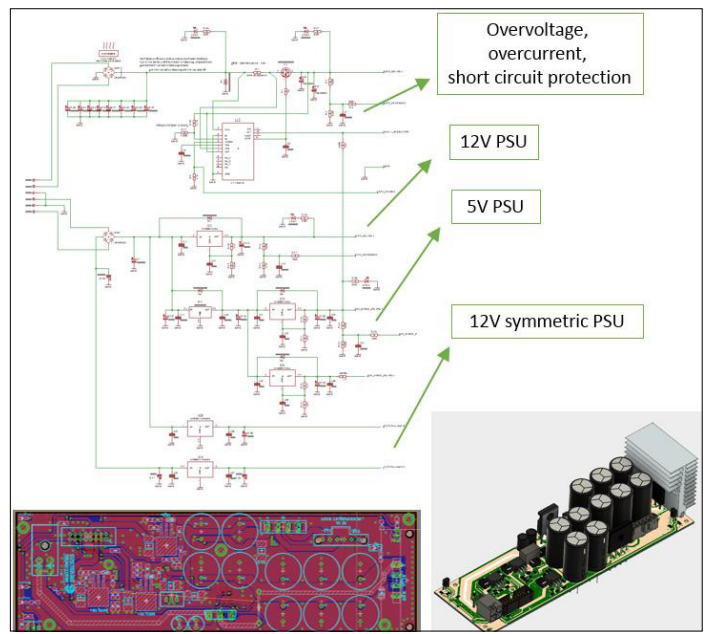

Figure 9. Power Supply schematic, PCB design, and $3 D$ model.

The double $\mathrm{H}$ bridge allows the measuring range to be switched in addition to changing current direction, therefore larger and smaller volume samples can be accurently examined.

The photo of the completed electronics is shown in Figure 7 and Figure 8 shows the different levels of design.

\subsection{Power supply electronics}

The power supply must produce several stabilized voltage levels, including $5 \mathrm{~V}$ for digital circuits, $\pm 12 \mathrm{~V}$ for fluxgate sensors, $36 \mathrm{~V}$ for solenoid drives. The schematic, the PCB design and the 3D model are shown in Figure 9.

The power supply uses the voltage generated by a $230 \mathrm{~V} / 36 \mathrm{~V}$ toroidal transformer, therefore mains isolation is implemented and electrical safety is ensured. A photograph of the completed

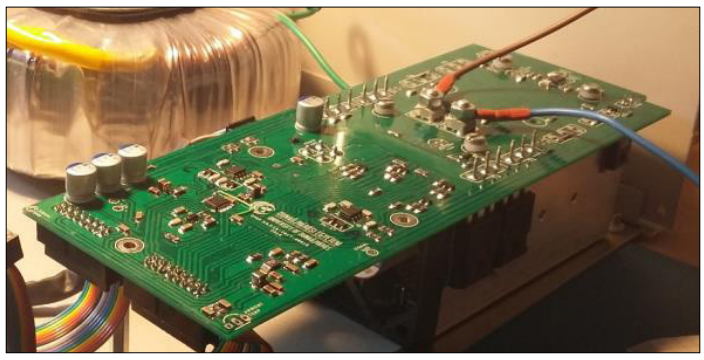

Figure 8. Manufactured and built-in coil drive electronics.

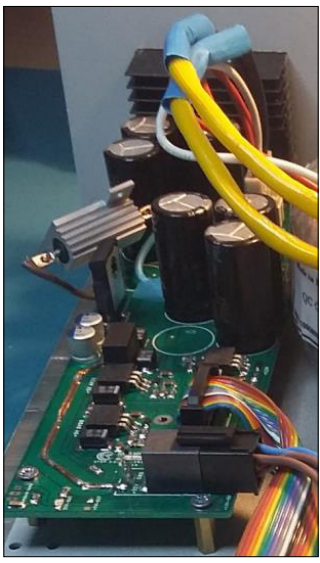

Figure 10. Power supply manufactured and installed.

power supply is shown in Figure 10. To handle the heat dissipation of the rectifying diode bridge, a heat sink is applied so that the heat is released outside of the enclosure. For accurate design, electrical and mechanical design have been performed side by side.

\subsection{Measurement controller and communi- cation unit}

A separate measurement control module has been developed to control the measurement process, to digitize the analog signals and to transfer the measured values to a computer. At the heart of the system is a 16-bit PIC microcontroller, the dsPIC30F6014A-30 from Microchip.

Figure 11 illustrates the circuit schematic, the PCB design and the 3D model of the unit. The unit is also equipped with a 4-line LCD to inform the user about the measurement process. Figure 12 shows the unit assembled with the front panel with the connecting ribbon cables.

During the design of the measurement control unit, galvanic isolation of the USB port had to be ensured so that neither the computer nor the unit would be damaged by a hot-plug event or a ground loop. This was accomplished with a 


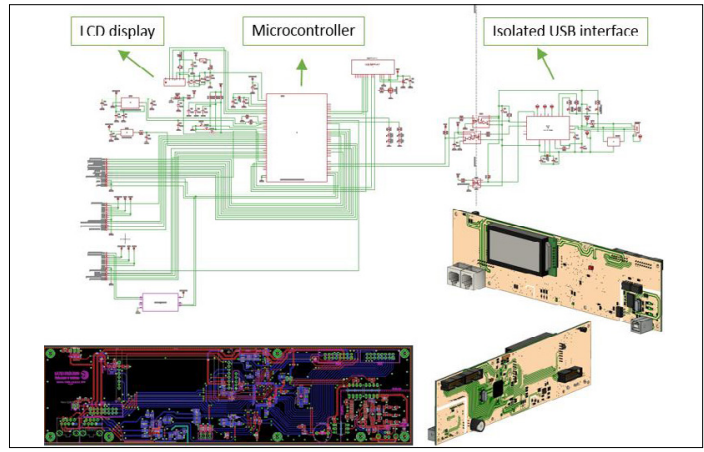

Figure 11. Wiring diagram of the controller, $P C B$ design and $3 D$ model.

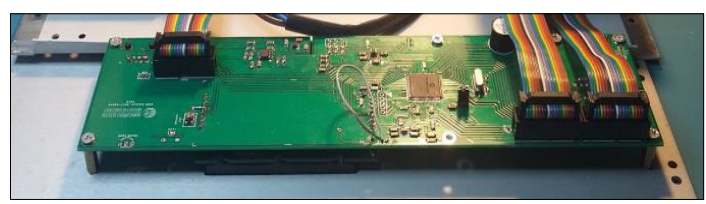

Figure 12. Measurement Controller manufactured and installed.

$6 \mathrm{kV}$ isolation voltage separator, interrupting the UART RX and TX lines.

USB communication is based on Virtual Serial Port (VCP) technology using an MCP 2200 integrated circuit. It is powered by the voltage supplied by the USB port of the PC and is therefore independent of the unit status

\section{Conclusions}

This article describes the design of magnetic testing equipment under development at the University of Dunaujvaros. The apparatus is capable of determining the B-H curve of small-volume ferromagnetic material samples using a homogeneous stationary magnetic field $(\mathrm{H})$ produced inside a solenoid. A fluxgate sensor was used in order to measure the magnetic field (B) of the sample. The main units are solenoid, solenoid drive unit, central measurement control unit, power supply and PC side software.

The development of the equipment is closely linked to research improving the efficiency of electric motors, which, inter alia, aims to reduce iron loss by using amorphous materials. The development of precise molding/die-cutting technology for these materials is essential for their application in the construction of electric motors. The technological parameters of the cut must be determined in such a way as to minimize the degrades of the excellent magnetic properties of the raw material.

\section{Acknowledgement}

This work is supported by the EFOP-3.6.1-16-201600003 and EFOP-3.6.2-16-2017-00016 project. Both of the projects are co-financed by the European Union.

\section{References}

[1] Wang Z. et al.: Development of an Axial Gap Motor With Amorphous Metal Cores. IEEE Transactions on Industry Applications, 47/3. (2011) 1293-1299. https://doi.org/10.1109/TIA.2011.2127430

[2] Kolano R., Krykowski K., Kolano-Burian A., Polak M., Szynowski J., Zackiewicz P.: Amorphous Soft Magnetic Materials for the Stator of a Novel HighSpeed PMBLDC Motor. IEEE Transactions on Magnetics, 49/4. (2013) 1367-1371. https://doi.org/10.1109/TMAG.2012.2234757

[3] Krings A., Boglietti A., Cavagnino A., Sprague S.: Soft Magnetic Material Status and Trends in Electric Machines. IEEE Transactions on Industrial Electronics, 64/3. (2017) 2405-2414, March. https://doi.org/10.1109/TIE.2016.2613844

[4] Yang W., Huang C., Zhang Q.: Optimization of Squirrel-Cage Rotor for Amorphous Asynchronous Motor. Chinese Automation Congress (CAC), Hangzhou, China, 2019, 2107-2110.

[5] A BIZOTTSÁG (EU) 2019/1781. rendelete (2019. október 1.) az elektromos motorokra és a frekvenciaváltókra vonatkozó környezettudatos tervezési követelményeknek a 2009/125/EK európai parlamenti és tanácsi irányelv szerinti megállapításáról, a 641/2009/EK rendeletnek a tömszelence nélküli önálló keringetőszivattyúkra és a termékbe beépített tömszelence nélküli keringetőszivattyúkra vonatkozó környezettudatos tervezési követelmények tekintetében történő módosításáról és a 640/2009/EK bizottsági rendelet hatályon kívül helyezéséről

[6] Global Efficiency Intelligence LLC.: Global Industrial Motor Systems Efficiency Initiative, https://www.globalefficiencyintel.com/global-industrial-motor-systems-initiative, January, 2020

[7] Szabo A., Koti D., Santa O., Kozsely G.: Development of the Shaping Method of Amorphous Ribbons Used in Electric Drives. XXXVI. International Colloquium Advanced Manufacturing and Repair Technologies in Vehicle Industry, Vol. XIX, 2019.

[8] Waide P., Brunner C.: Energy-Efficiency Policy Opportunities for Electric Motor-Driven Systems. IEA Energy Papers, 7. (2011), OECD Publishing, https://doi.org/10.1787/5kgg52gb9gjd-en

[9] Sheiretov Y.: Deep Penetration Magnetoquasistatic Sensors. Doctor of Philosophy at the Massachusetts Institute of Technology, June 2001

[10] Dirk Ettelt.: Conception et fabrication d'un magnétomètre à jauge de contrainte. Université de Grenoble, 2012, French, https://tel.archives-ouvertes.fr/tel-00744722 